\title{
The Reactivity of Desmosterol and Other Shellfish- and Xanthomatosis- associated Sterols in the Macrophage Sterol Esterification Reaction
}

Ira Tabas, ${ }^{\star \ddagger}$ Steven J. Feinmark, ${ }^{\star \S}$ and Nanda Beatini ${ }^{\star}$

Departments of ${ }^{*}$ Medicine, ${ }^{\ddagger}$ Cell Biology, and ${ }^{\S}$ Pharmacology, Columbia University

College of Physicians and Surgeons, New York, New York 10032

\begin{abstract}
The acyl-CoA: cholesterol acyl transferase (ACAT) reaction in macrophages is a critical step in atherosclerotic foam cell formation, but little is known about the reaction's sterol substrate specificity. In this report we examine the macrophage ACAT reactivity of the shellfish sterol, desmosterol, and other sterols found in man because of shellfish ingestion or in association with the foam cell diseases sitosterolemia and cerebrotendinous xanthomatosis (CTX). We first show that the J774 macrophage, a foam cell model with a hyperactive ACAT pathway, synthesizes desmosterol instead of cholesterol and that both endogenous and exogenous desmosterol are substrates and stimulators of the ACAT reaction in these cells. When exogenous desmosterol was added to human monocytederived macrophages, ACAT was stimulated 29- and 4-fold compared with control and cholesterol-treated cells, respectively. Steryl ester mass accumulation in desmosterol-treated human macrophages was 10-fold greater than in control cells and 3-fold greater than in cholesterol-treated cells. Another shellfish sterol, 24-methylene cholesterol, also stimulated ACAT in human macrophages, but most of the xanthomatosis-related sterols did not stimulate ACAT. These data suggest that: $(a)$ the shellfish sterols desmosterol and 24-methylene cholesterol may be atherogenic; and $(b)$ the excessive foam cell formation seen in sitosterolemia and CTX cannot be explained by ACAT hyperreactivity of their associated sterols.
\end{abstract}

\section{Introduction}

Early atherogenesis is characterized by the appearance in the subendothelium of numerous cholesteryl ester $(\mathrm{CE})^{1}$-filled macrophages or foam cells (1-3). The precise cellular and molecular mechanisms of foam cell formation are not known. LDL stimulates the accumulation of CE in two tissue culture macrophages, the mouse peritoneal macrophage and the

Address correspondence to Dr. Ira Tabas, Department of Medicine, Columbia University College of Physicians and Surgeons, 630 West 168th St., New York, NY 10032. 1989

Received for publication 11 April 1989 and in revised form 27 June

1. Abbreviations used in this paper: ACAT, acyl-CoA:cholesteryl ester transferase; CE, cholesteryl ester; CTX, cerebrotendinous xanthomatosis; GC, gas chromatography; GC-MS, gas chromatography-mass spectrometry; LPDS, lipoprotein-deficient serum.

J. Clin. Invest.

(C) The American Society for Clinical Investigation, Inc.

0021-9738/89/12/1713/09 \$2.00

Volume 84, December 1989, 1713-1721 human monocyte-derived macrophage, only after the lipoprotein has been modified to a form recognized by the scavenger receptor; this receptor, unlike the $\mathrm{LDL}$ receptor, is not downregulated by cholesterol (4). In mouse peritoneal macrophages native LDL can induce CE accumulation only when the cells are in a protein synthesis-inhibited state (5). In a third tissue culture macrophage, the J774 murine macrophage cell line, both modified and native LDL induce foam cell formation, even when the cells are not protein synthesis inhibited $(5,6)$.

In each of these three foam cell models $\mathrm{CE}$ accumulation occurs in parallel with activation of the intracellular cholesterol esterifying enzyme, acyl-CoA:CE transferase (ACAT). ACAT is known to catalyze the esterification of fatty acid with internalized lipoprotein-derived cholesterol (reviewed in reference 7) as well as with endogenous cellular cholesterol $(8,9)$. Unfortunately, ACAT has not yet been purified so the properties and regulation of this enzymatic pathway are poorly understood. Nonetheless, there is good evidence to suggest that the ACAT pathway plays an important role in foam cell formation. Not only does ACAT catalyze the formation of the CE that accumulates in foam cells (4), but it can also influence other aspects of intracellular cholesterol metabolism that may be important in foam cell formation. For example, hyperactive ACAT in $\mathbf{J} 774$ macrophages leads to diminished downregulation of the LDL receptor; this process allows the internalization of large amounts of LDL, which in turn contributes to LDL-induced foam cell formation in these cells (10).

We have been interested in investigating factors that may regulate the ACAT pathway. One class of potential stimulatory factors are certain noncholesterol sterols. These compounds are of particular interest for the following reasons: $(a)$ microsomal $\mathrm{ACAT}^{2}$ studies have revealed that certain noncholesterol sterols can be esterified as well as or better than cholesterol $(11,12) ;(b)$ two human diseases in which there is prominent foam cell formation and premature atherosclerosis, sitosterolemia and cerebrotendinous xanthomatosis (CTX), are characterized by elevated plasma and tissue levels of noncholesterol sterols such as plant sterols $(13,14)$; and $(c)$ several noncholesterol sterols, such as desmosterol and 24-methylene cholesterol, are abundant in certain types of shellfish, such as Alaskan king crab (15) and oysters, clams, and scallops (16) and are intestinally absorbed (17). Furthermore, desmosterol, in particular, has been implicated to be atherogenic in animals $(18,19)$.

Herein we explore the effect of desmosterol and other sterols on the ACAT pathway in macrophages. Our investiga-

2. For the sake of convention we will refer to intracellular sterol esterification activity (whether cholesterol or other sterols are esterified) as ACAT activity. 
tion was stimulated by the unexpected discovery that $\mathbf{J 7 7 4}$ macrophages have a complete defect in cholesterol biosynthesis and instead accumulate desmosterol. Our report, therefore, evaluates the role of endogenous desmosterol on the ACAT pathway in $\mathbf{J 7 7 4}$ macrophages and explores the effect of exogenous desmosterol and other sterols on the ACAT pathway in human monocyte-derived macrophages.

\section{Methods}

Materials. DME, RPMI 1640 medium, penicillin $(10,000 \mathrm{U} / \mathrm{ml})$ and streptomycin $(10,000 \mu \mathrm{g} / \mathrm{ml})$ solutions, and glutamine $(200 \mathrm{mM})$ solution were obtained from Gibco Laboratories (Grand Island, NY). Defined fetal bovine serum (lot No. 1111683) and iron-supplemented calf serum were obtained from Hyclone Laboratories (Logan, UT). Human serum (type $\mathrm{A}, \mathrm{Rh}^{+}$) was obtained from normal human volunteers. The Falcon tissue culture plasticware used in these studies was purchased from Fisher Scientific Co. (Pittsburgh, PA). Desmosterol $(5,24$-cholestadien-3 $\beta$-ol) and lanosterol $(8,24,[5]$-cholestadien$4,4,14 \alpha$-trimethyl-3 $\beta$-ol) were purchased from Steraloids, Inc. (Wilton, $\mathrm{NH}$ ) and cholesterol (5-cholesten-3 $\beta$-ol) was obtained from Nu Check Prep, Inc. (Elysian, MN); all three sterols were purified by HPLC before use. Brassicasterol (5,22-cholestadien-24 $\beta$-methyl-3 $\beta$-ol),

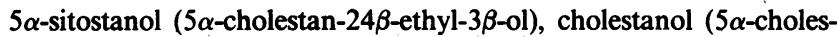
$\tan -3 \beta$-ol), $5 \alpha$-campestanol ( $5 \alpha$-cholestan- $24 \alpha$-methyl-3 $\beta$-ol), 24 methylene cholesterol $(5,24(28)$-cholestadien-24-methylen-3 $\beta$-ol), campesterol (5-cholesten- $24 \alpha$-methyl-3 $\beta$-ol), and $\beta$-sitosterol (5-cholesten-24 $\beta$-ethyl-3 $\beta$-ol) were purchased from Research Plus, Inc. (Bayonne, NJ). Lovastatin (mevinolin) was kindly provided by Alfred W. Alberts (Merck Sharp, \& Dohme Research Laboratories, Rahway, $\mathrm{NJ}$ ). Before addition to the tissue culture medium, the compound was converted to the sodium salt as described previously (20). Triparanol (MDL 5052) was a gift of Merrel Dow Research Institute (Cincinnati, $\mathrm{OH})$; a stock solution of $1 \mathrm{mM}(0.44 \mathrm{mg} / \mathrm{ml})$ in ethanol was made before use. Compound 58-035 was generously provided by Dr. John Heider of Sandoz, Inc. (East Hanover, NJ); a stock solution of 10 $\mathrm{mg} / \mathrm{ml}$ in dimethyl sulfoxide was made before use. $\left[5-{ }^{3} \mathrm{H}\right]$ Mevalonolactone, $\left[4-{ }^{14} \mathrm{C}\right]$ cholesterol, $\left[1-{ }^{14} \mathrm{C}\right]$ oleic acid, and $\left[1,2,6,7-{ }^{3} \mathrm{H}\right]$ cholesteryl oleate were purchased from New England Nuclear (Boston, MA).

Cells. Monolayer cultures of $\mathrm{J} 774$ cells and human foreskin fibroblasts (sixth passage) were grown and maintained in DME containing $10 \%$ (vol/vol) fetal bovine serum, penicillin $(100 \mathrm{U} / \mathrm{ml})$, streptomycin $(100 \mu \mathrm{g} / \mathrm{ml})$, and glutamine $(292 \mu \mathrm{g} / \mathrm{ml})$ as described previously (6). Unless otherwise noted, the cells were plated at $20 \%$ confluency and then incubated for $2-3 \mathrm{~d}$ at $37^{\circ} \mathrm{C}$ in an atmosphere containing $8 \%$ $\mathrm{CO}_{2} / 92 \%$ air. Mouse peritoneal macrophages were obtained from the peritoneum of thioglycollate-stimulated mice (male, strain ICR, 25-35 g, from Harlan Sprague Dawley, Inc. [Indianapolis, IN]) injected intraperitoneally with $1 \mathrm{ml}$ thioglycollate broth $4 \mathrm{~d}$ before cell harvest, as described previously for unstimulated mice (21). The cells were plated at a density of $10^{6}$ cells $/ 35-\mathrm{mm}$ dish and maintained in $\mathrm{DME} / 10 \%$ fetal bovine serum for 1-2 d before use. Human monocyte-derived macrophages from leukocyte-rich concentrates (New York Blood Center, New York, NY) were isolated from Ficoll-Hypaque (Pharmacia Fine Chemicals, Piscataway, NJ) gradients and cultured in Teflon beakers for $2 \mathrm{wk}$ in RPMI/10\% human serum as described (22). The cells were plated at a density of $10^{6}$ cells $/ 35-\mathrm{mm}$ dișh and maintained in RPMI $/ 10 \%$ human serum for $2-3 \mathrm{~d}$ before use. Mouse L cells (NCTC clone 929) were obtained from the American Type Culture Collection (Rockville, MD) and grown and maintained in DME/10\% calf serum. For most experiments cells were incubated for $24 \mathrm{~h}$ before the beginning of the experiment with DME/10\% lipoprotein-deficient serum (LPDS).

Lipoproteins. LDL (density, $1.020-1.063 \mathrm{~g} / \mathrm{ml}$ ) from fresh human plasma and LPDS $(d=1.215 \mathrm{~g} / \mathrm{ml})$ from fetal bovine serum or human serum were isolated by preparative ultracentrifugation.
Preparation of nonsaponifiable lipids from cells and medium. The cell monolayers were first washed three times with cold PBS. The J774 monolayers were scraped with a rubber policeman and after an aliquot was removed for protein determination (23) the cellular lipids were extracted by the method of Folch et al. (24). The lipids of human fibroblasts, mouse peritoneal macrophages, and human monocyte-derived macrophages were extracted directly from the monolayers in the culture dishes with hexane/isopropanol (3:2 vol/vol; 25$)$. The remaining nonlipid cellular material was dissolved in $0.1 \mathrm{~N} \mathrm{NaOH}$ and assayed for protein content (23). The lipids of the tissue culture media were extracted by the method of Bligh and Dyer (26). Each of the extraction solvents contained a specified amount of $\left[{ }^{14} \mathrm{C}\right]$ cholesterol standard. The lipid residue was recovered after the solvents were removed under nitrogen and $0.2 \mathrm{ml} 50 \%$ (wt/vol) $\mathrm{KOH}$ and $3.0 \mathrm{ml}$ methanol were added to each. After heating for $1 \mathrm{~h}$ at $80^{\circ} \mathrm{C}, 3.0 \mathrm{ml}$ $\mathrm{H}_{2} \mathrm{O}$ and $5.0 \mathrm{ml}$ hexane were added and the nonsaponifiable lipids were recovered in the hexane phase. The solvent was removed under nitrogen and the lipid residue was dissolved in ethanol for HPLC injection.

Reverse-phase HPLC of nonsaponifiable lipids. The procedure was a modification of that of Trzaskos et al. (27). The nonsaponifiable lipids in ethanol $(40 \mu \mathrm{l})$ were injected by a WISP autoinjector (Waters Associates, Milford, MA) onto a 5- $\mu \mathrm{m}$ LiChrosorb RP-8 column (4.6 $\mathrm{mm} \times 25 \mathrm{~cm}$; Alltech Associates, Inc., Deerfield, IL) equipped with a 3-cm RP-8 guard column. The column was eluted with acetonitrile/ methanol $/ \mathrm{H}_{2} \mathrm{O}(45: 45: 10 \mathrm{vol} / \mathrm{vol} / \mathrm{vol})$ at a flow rate of $1 \mathrm{ml} / \mathrm{min}$ at room temperature using a solvent delivery system (model 6000A; Waters Associates). 40 fractions $(0.5 \mathrm{ml})$ were collected and analyzed for radioactivity by liquid scintillation counting (model LS 5801; Beckman Instruments, Inc., Palo Alto, CA) or mass by gas chromatography (GC; see below)

Sterol mass assay. Cellular lipid extracts and HPLC fractions (see above) were assayed for free and esterified sterol content by gas-liquid chromatography as previously described (6). A 3-ft glass column (2-1838; Supelco, Inc., Bellefonte, PA) packed with 3\% OV-17 was used on a gas chromatograph (model 5890; Hewlett-Packard Co., Palo Alto, CA). The $\mathrm{N}_{2}$ carrier gas flow rate was $40 \mathrm{ml} / \mathrm{min}$, the injector and detector temperatures were $275^{\circ} \mathrm{C}$, and the oven temperature was $255^{\circ} \mathrm{C}$. $\beta$-Sitosterol was used as an internal standard.

Analytical TLC. Two TLC systems were used to analyze the major $\left[{ }^{3} \mathrm{H}\right]$ mevalonate-derived lipid from $\mathrm{J} 774$ cells using synthetic cholesterol, lanosterol, and desmosterol as standards: silica gel $\mathbf{G}$ developed in chloroform and silica gel $\mathrm{G}$ pretreated with a $20 \%$ solution of $\mathrm{AgNO}_{3}$ (argentation TLC) developed in chloroform/ether/acetic acid (97:2.3:0.5 vol/vol/vol) (28). The $\boldsymbol{R}_{\mathrm{f}}$ values for cholesterol, lanosterol, and desmosterol in the first system were, respectively, $0.27,0.39$, and 0.27 ; in the second (argentation) system the respective values were $0.27,0.27$, and 0.21 .

Catalytic reduction. Sterols were dissolved in a small volume of methanol (1-5 mg in $0.5 \mathrm{ml}$ ) and cooled on ice. Platinum (IV) oxide ( $\sim 1 \mathrm{mg}$ ) was added and hydrogen gas was bubbled through the methanol for $2 \mathrm{~min}$. The catalyst was removed by passing the reaction mixture through a glass wool-plugged pipet and the solvent was removed under a stream of argon. Reduced sterols were then analyzed by GC or GC-mass spectrometry (GC-MS) as described below.

$G C-M S$. Sterols dissolved in hexane were analyzed on a HP5987A GC-MS fitted with a 12-mDB-1 capillary column. The GC was held at $270^{\circ} \mathrm{C}$ for $1 \mathrm{~min}$ and then programmed to $300^{\circ} \mathrm{C}$ at a rate of $30^{\circ} \mathrm{C} /$ min. The injector and transfer lines were maintained at 270 and $275^{\circ} \mathrm{C}$, respectively, and the source was $200^{\circ} \mathrm{C}$.

Whole-cell $A C A T$ assay. ACAT activity was assayed in intact cells by the $\left[{ }^{14} \mathrm{C}\right]$ oleate-albumin pulse method exactly as described previously (21).

Sterol cell association assay. Cell monolayers were incubated with DME/10\% LPDS containing $10 \mu \mathrm{g} / \mathrm{ml}(2.9 \mu \mathrm{Ci} / \mu \mathrm{mol})$ of the $\left[{ }^{3} \mathrm{H}\right]-$ mevalonate-derived lipid from $\mathbf{J} 774$ cells (see Fig. 1, bottom, fractions $18-20)$ and $10 \mu \mathrm{g} / \mathrm{ml}(1.9 \mu \mathrm{Ci} / \mu \mathrm{mol})\left[{ }^{14} \mathrm{C}\right]$ cholesterol for 2,4 , and 6 (or 7) $\mathrm{h}$ at $37^{\circ} \mathrm{C}$. The mixture of labeled sterols was added to the media 
from a stock solution in ethanol such that the final concentration of ethanol in the media was $0.33 \%$ ( $\mathrm{vol} / \mathrm{vol})$. At the end of each time point the cells were washed thoroughly with cold PBS and then extracted for lipid and assayed for protein as described above. To the dried lipid extracts was added $4.0 \mathrm{ml}$ Hydrofluor (National Diagnostics, Inc., Somerville, NJ), and the samples were assayed for radioactivity by liquid scintillation counting with automatic quench control. All values were corrected for channel crossover. Based on the specific activity of the sterols in the media added to the cells, the data (means \pm SEM, $n$ $=3$ ) were expressed as cell-associated labeled sterol/milligram cell protein.

\section{Results}

J774 macrophages have a complete defect in cholesterol biosynthesis and instead synthesize desmosterol. Sterol biosynthesis in $\mathbf{J 7 7 4}$ macrophages was compared with that in human skin fibroblasts after pulse labeling for $1 \mathrm{~h}$ with DME/LPDS containing $\left[{ }^{3} \mathrm{H}\right]$ mevalonate followed by incubation for $24 \mathrm{~h}$ with DME/LPDS alone. The nonsaponifiable lipid fractions of the cells were then subjected to reverse-phase HPLC analysis (Fig. 1). In human fibroblasts (Fig. 1, top) $85 \%$ of the tritium-

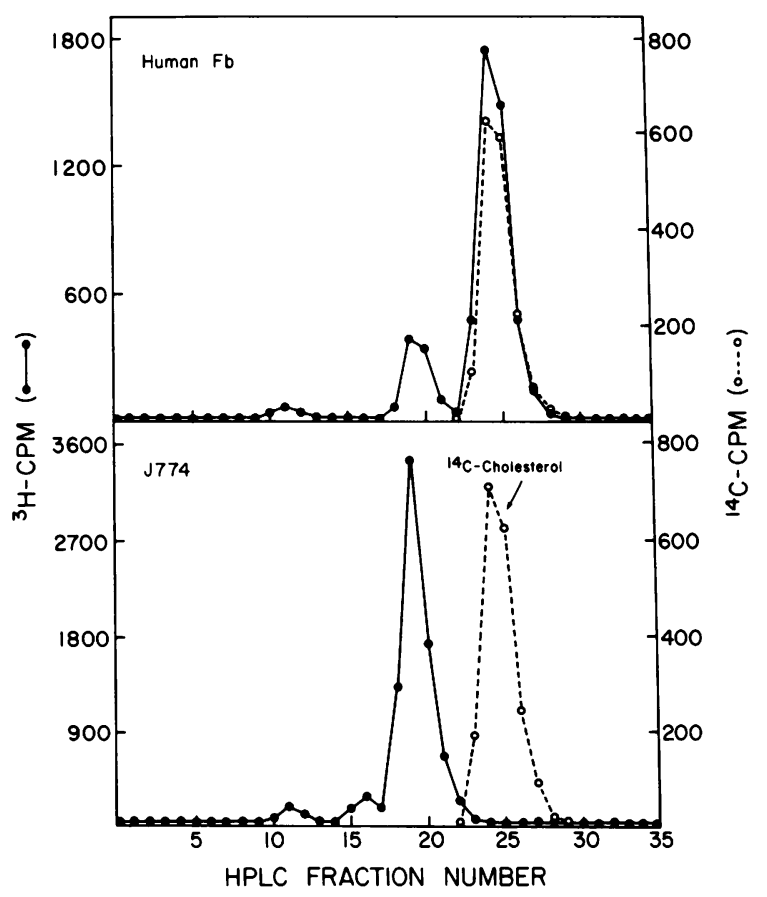

Figure 1. HPLC of $\left[{ }^{3} \mathrm{H}\right]$ mevalonate-derived, nonsaponifiable lipids from human fibroblasts and $\mathbf{J} 774$ macrophages. Subconfluent monolayers of human fibroblasts (top) and $\mathrm{J} 774$ macrophages (bottom) were preincubated for $24 \mathrm{~h}$ in DME/10\% LPDS and then incubated with DME/LPDS containing $\left[{ }^{3} \mathrm{H}\right]$ mevalonate $(0.3 \mu \mathrm{M}, 38.8 \mu \mathrm{Ci} /$ $\mathrm{nmol}$ ) for $1 \mathrm{~h}$ at $37^{\circ} \mathrm{C}$. The cells were then washed with PBS and incubated for $24 \mathrm{~h}$ at $37^{\circ} \mathrm{C}$ with DME/LPDS alone. At the end of the 24-h incubation, $\left[{ }^{14} \mathrm{C}\right]$ cholesterol internal standard was added and the cellular lipids were extracted. After alkaline hydrolysis the cellular lipids were subjected to reverse phase C-8 HPLC analysis as described in Methods. The HPLC fractions were then analyzed for $\left[{ }^{3} \mathrm{H}\right]$ $(\bullet)$ and $\left[{ }^{14} \mathrm{C}\right](\mathrm{O})$ radioactivity by liquid scintillation counting. The recovery of the radioactivity in the HPLC fractions for both cell types (expressed as a percentage of that added to the column) was $\sim 80 \%$. The protein contents of the fibroblast and $\mathrm{J} 774$ monolayers were 1.6 and $2.3 \mathrm{mg}$, respectively. This figure is typical of four separate experiments. labeled, nonsaponifiable lipids coeluted with $\left[{ }^{14} \mathrm{C}\right]$ cholesterol standard. Similar analysis in mouse peritoneal macrophages and human monocyte-derived macrophages revealed that 52 and $73 \%$, respectively, of the labeled nonsaponifiable lipids coeluted with authentic cholesterol. In contrast, in J774 macrophages (Fig. 1, bottom) none of the labeled material coeluted with authentic cholesterol. Rather, most of the label accumulated in a fraction that eluted earlier than cholesterol. Longer chase times (up to $48 \mathrm{~h}$ ) did not change this pattern. The tritium-labeled, nonsaponifiable lipids in the $\mathrm{J} 774$ chase medium accounted for $<10 \%$ of the labeled material extracted from the cells; HPLC analysis of these lipids revealed no labeled material coeluting with $\left[{ }^{14} \mathrm{C}\right]$ cholesterol standard. When human fibroblasts were pulse-labeled with exogenously added tritiated $\mathrm{J} 774$ lipid (isolated by HPLC, dissolved in ethanol, and added to DME/LPDS), $97 \%$ of the label was converted to cholesterol (by HPLC analysis) after a 24-h chase; there was no conversion of the labeled material when it was exogenously added to $\mathbf{J} 774$ macrophages (data not shown). Thus, J774 macrophages were unable to convert exogenous mevalonate to cholesterol but instead accumulated another nonsaponifiable lipid. This lipid was converted to cholesterol in human fibroblasts and thus is a potential biosynthetic precursor of cholesterol in these cells, but was not further metabolized when added exogenously to $\mathrm{J} 774$ cells.

To further explore this finding we measured the mass of the nonsaponifiable lipids that accumulated in $\mathrm{J} 774$ macrophages that had been grown in DME/LPDS for $9 \mathrm{~d}$. We first determined that the major nonsaponifiable lipid that accumulated in these cells was indistinguishable from the product of J774 $\left[{ }^{3} \mathrm{H}\right]$ mevalonate metabolism after HPLC and argentation TLC (see below). In addition, the GC analysis disclosed that the J774 lipid had a longer retention time than cholesterol. Therefore, it was possible to analyze the nonsaponifiable lipids of LPDS-incubated $\mathbf{J} 774$ cells directly by GC (without prior HPLC). Using this method we found that the J774 cells contained $0.4 \mu \mathrm{g}$ cholesterol/mg cell protein (1\%) and $40.9 \mu \mathrm{g} / \mathrm{mg}$ of the other lipid (99\%). Thus, when $\mathbf{J} 774$ cells were allowed to grow in the absence of an external source of cholesterol the cells contained very little cholesterol but rather contained another nonsaponifiable lipid. These data corroborate the $\left[{ }^{3} \mathrm{H}\right]$ mevalonate data in Fig. 1 and further show that $\mathbf{J} 774$ cells have a major defect in cholesterol biosynthesis.

To determine the structure of the lipid that accumulates in J774 cells, the major nonsaponifiable lipid of LPDS-incubated J774 cells was isolated by HPLC and several procedures were performed. The $\mathrm{J} 774$ lipid comigrated on a standard and an argentation TLC system (see Methods) with 5,24-cholestadien- $3 \beta$-ol (desmosterol) standard; the $R_{\mathrm{f}}$ value of the $\mathrm{J} 774$ lipid and desmosterol standard on argentation TLC was 0.21 , whereas the $R_{\mathrm{f}}$ of cholesterol and lanosterol was 0.27 . Desmosterol and the $\mathbf{J 7 7 4}$ lipid had identical elution profiles on reverse phase C-8 HPLC and had identical retention times on GC (OV-17, packed column and DB-1, capillary column). Catalytic reduction of the $\mathbf{J} 774$ lipid yielded a product that had a GC retention time identical to reduced cholesterol. Finally, the mass spectrum of the $\mathbf{J} 774$ lipid was indistinguishable from desmosterol standard. Major ions were detected at $\mathrm{m} / \mathrm{z} 384$ $\left(\mathbf{M}^{+}\right), 369\left(\mathbf{M}^{+}-15\right), 366\left(\mathbf{M}^{+}-18\right), 351\left(\mathbf{M}^{+}-[15+18]\right)$, 300,271 , and 69 (base peak). Furthermore, catalytic reduction of the $\mathrm{J} 774$ lipid increased the mass of the molecular ion by 4 , indicating the presence of two double bonds. The spectrum of 
the reduced lipid was identical to that of reduced cholesterol, which indicates that the $\mathbf{J 7 7 4}$ lipid differs from cholesterol only by the presence of one additional double bond. The abundant presence of an ion at $\mathrm{m} / \mathrm{z} 69$ in the $\mathrm{J774}$ lipid mass spectrum is typical of the fragmentation at delta- 24 in the sterol side chain (29). The $\mathrm{J} 774$ sterol is indistinguishable from desmosterol by these criteria.

Desmosterol is an ACAT substrate and stimulator in $J 774$ macrophages. The ability of $\mathbf{J 7 7 4}$ macrophages to accumulate CE is dependent on a very active ACAT pathway in these cells (10). We therefore sought to determine if a relationship existed between the cells' active ACAT pathway and their block in cholesterol biosynthesis. We were specifically interested in determining if desmosterol, the sterol that accumulates in $\mathbf{J 7 7 4}$ macrophages (above), was a substrate and/or a stimulator of ACAT in these cells.

We first examined the steryl esters made in LPDS-preincubated J774 macrophages to determine if endogenously synthesized desmosterol was a substrate for J774 ACAT. When J774 cells were pulse labeled with DME/LPDS containing $\left[{ }^{3} \mathrm{H}\right]$ mevalonate for $5 \mathrm{~h}$ at $13^{\circ} \mathrm{C}$ and then chased for $2 \mathrm{~h}$ at $37^{\circ} \mathrm{C}$ in DME/LPDS alone, $36.4 \%$ of the cellular $\left[{ }^{3} \mathrm{H}\right]$ sterol was esterified. The steryl ester fraction from these cells was isolated by TLC and subjected to alkaline hydrolysis; the steryl ester-derived $\left[{ }^{3} \mathrm{H}\right]$ sterols were then analyzed by reverse phase HPLC (Fig. 2). None of the radioactivity coeluted with authentic cholesterol. Rather, there was a major peak of radioactivity

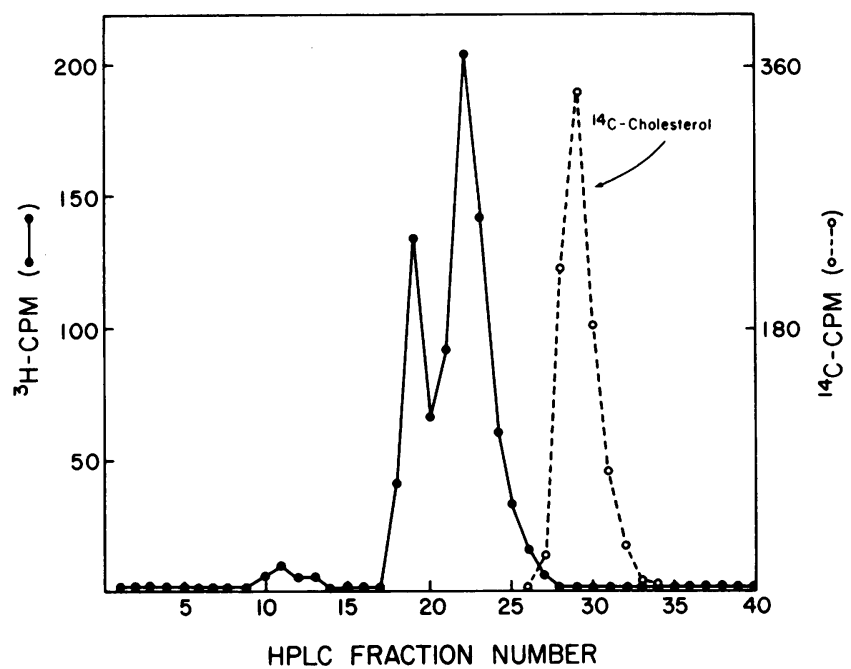

Figure 2. HPLC of the $\left[{ }^{3} \mathrm{H}\right]$ sterol moieties of $\left[{ }^{3} \mathrm{H}\right]$ mevalonate-derived $\left[{ }^{3} \mathrm{H}\right]$ steryl esters from $\mathbf{J} 774$ macrophages. A subconfluent monolayer of $\mathrm{J} 774$ macrophages, preincubated for $24 \mathrm{~h}$ in DME/LPDS, was incubated with DME/LPDS containing $\left[{ }^{3} \mathrm{H}\right]$ mevalonate $(0.7 \mu \mathrm{M}, 38.8$ $\mu \mathrm{Ci} / \mathrm{nmol})$ for $5 \mathrm{~h}$ at $15^{\circ} \mathrm{C}$. The cells were then washed with PBS and incubated for $2 \mathrm{~h}$ at $37^{\circ} \mathrm{C}$ in DME/LPDS containing $2 \mathrm{mM}$ unlabeled mevalonate. Lipid extracts of the cells were then fractionated by TLC (silica gel G developed in petroleum ether/diethyl ether/acetic acid, 90:10:1, vol/vol/vol), and the steryl ester spot was scraped and extracted with chloroform containing authentic $\left[{ }^{14} \mathrm{C}\right]$ cholesterol. The extracts were then subjected to alkaline hydrolysis and analyzed by HPLC as described in the legend to Fig. 1, except that $0.2 \mathrm{ml}$ from each $0.5-\mathrm{ml}$ fraction was counted $\left(\bullet,\left[{ }^{3} \mathrm{H}\right] \mathrm{cpm} ; \circ,\left[{ }^{14} \mathrm{C}\right] \mathrm{cpm}\right)$. The protein content of the $\mathrm{J} 774$ monolayer was $5.5 \mathrm{mg}$. Recovery of the radioactivity applied to the HPLC column was $\sim 80 \%$. These data are typical of two separate experiments. that eluted several minutes earlier than cholesterol; this material was subsequently shown to coelute with authentic desmosterol on HPLC and argentation TLC. There was also a minor peak of radioactivity eluting shortly before the major peak of radioactivity; the identity of the material in this peak has not yet been determined. In control experiments using synthetic $\left[{ }^{3} \mathrm{H}\right]$ cholesteryl ester the TLC-HPLC method described above produced a single peak of tritium-labeled material on HPLC that coeluted with $\left[{ }^{14} \mathrm{C}\right]$ cholesterol standard. Thus, $\mathbf{J 7 7 4}$ cells incubated in LPDS synthesize desmosterol and convert this endogenous sterol to desmosteryl ester.

We next addressed the issue of ACAT stimulation by desmosterol. As shown in Fig. $3 A(C O N)$, J774 cells that had been both preincubated and incubated in DME/LPDS (to accentuate endogenous desmosterol synthesis) had relatively high ACAT activity despite the absence of any exogenous lipoproteins or sterol. In contrast, when human fibroblasts and mouse peritoneal macrophages were incubated under indentical conditions ACAT activity was $0.33 \pm 0.04$ and $0.34 \pm 0.08$ $\mathrm{nmol} / \mathrm{mg}$ cell protein per $\mathrm{h}$, respectively, fivefold less than J774 ACAT activity. When J774 cells were treated for $14 \mathrm{~h}$ with lovastatin $(10 \mu \mathrm{M})$, an inhibitor of $\mathrm{HMG}-\mathrm{CoA}$ reductase
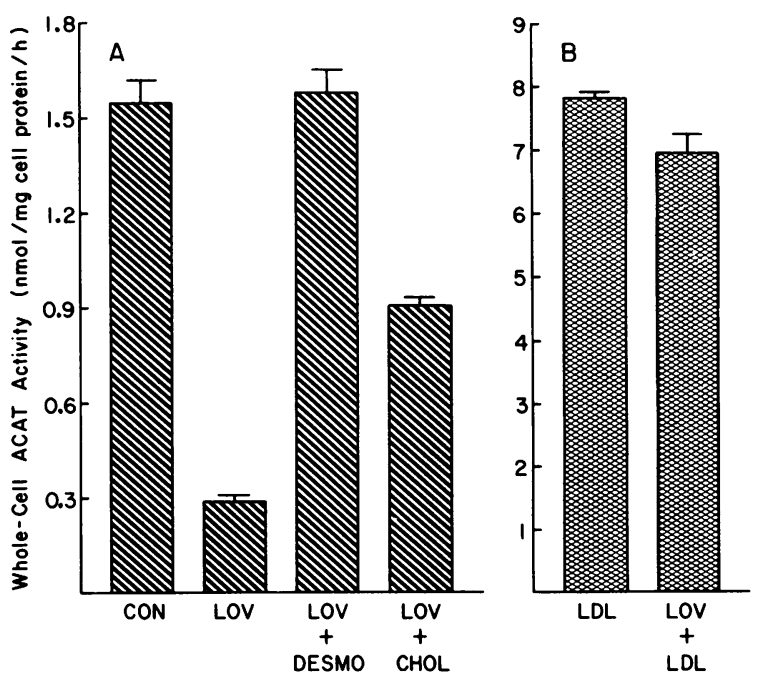

Figure 3. Whole-cell ACAT activity in control and lovistatin-treated J774 macrophages treated with desmosterol, cholesterol, or LDL. Monolayers of $\mathrm{J} 774$ macrophages were first incubated for $10 \mathrm{~h}$ with DME/10\% LPDS and then for an additional $14 \mathrm{~h}$ with DME/10\% LPDS alone ( $A$, first bar; $B$, first bar) or with DME/LPDS containing $10 \mu \mathrm{M}$ lovistatin ( $A$, bars 2,3 , and $4 ; B$, bar 2 ). The cells were then incubated for $6 \mathrm{~h}$ with DME/LPDS alone ( $A$, first bar) or with DME/ LPDS containing $10 \mu \mathrm{M}$ lovistatin ( $A$, second bar), lovistatin plus 10 $\mu \mathrm{g} / \mathrm{ml}$ desmosterol ( $A$, third bar), lovistatin plus $10 \mu \mathrm{g} / \mathrm{ml}$ cholesterol ( $A$, fourth bar), $100 \mu \mathrm{g} / \mathrm{ml}$ LDL ( $B$, first bar), or lovistatin plus LDL ( $B$, second bar). Desmosterol and cholesterol were added to the media from stock solutions in ethanol so that all incubations, including controls, contained $0.33 \%$ ( $\mathrm{vol} / \mathrm{vol})$ ethanol. During the last hour of the 6-h incubation the cells were incubated with $\left[{ }^{14} \mathrm{C}\right]$ oleatealbumin complex; at the end of the 6-h incubation the cells were assayed for steryl $\left[{ }^{14} \mathrm{C}\right]$ oleate content per milligram protein per $35-\mathrm{mm}$ dish as described in Methods. Values shown are means \pm SEM from three experiments. Note the different ordinate scales in $A$ and $B$. Separate experiments with $10 \mu \mathrm{g} / \mathrm{ml}\left[{ }^{3} \mathrm{H}\right]$ desmosterol and $\left[{ }^{14} \mathrm{C}\right] \mathrm{choles}-$ terol indicated that the cells (under the exact same conditions as this whole-cell ACAT experiment) took up in $6 \mathrm{~h}$ (per milligram cell protein) $2.24 \pm 0.15 \mu \mathrm{g}$ desmosterol and $2.13 \pm 0.15 \mu \mathrm{g}$ cholesterol. 
(30), $\left[{ }^{3} \mathrm{H}\right]$ mevalonate conversion to desmosterol was completely blocked (data not shown). Under these conditions (Fig. $3 \mathrm{~A}[\mathrm{LOV}]$ ) ACAT activity diminished to $<20 \%$ of the control value. Incubation of the lovastatin-treated $\mathrm{J} 774$ cells with 10 $\mu \mathrm{g} / \mathrm{ml}$ desmosterol (either obtained commercially or purified from LPDS-incubated J774 cells) restored the level of ACAT activity to the control value (Fig. $3 A[L O V+D E S M O]$ ), whereas incubation of the cells with $10 \mu \mathrm{g} / \mathrm{ml}$ cholesterol only partially restored ACAT activity (Fig. $3 \mathrm{~A}[\mathrm{LOV}+\mathrm{CHOL}]$ ). The difference in ACAT stimulation between desmosterol and cholesterol could not be accounted for by greater desmosterol uptake; in lovastatin-treated $\mathrm{J} 774$ cells incubated with 10 $\mu \mathrm{g} / \mathrm{ml}\left[{ }^{3} \mathrm{H}\right]$ desmosterol plus $10 \mu \mathrm{g} / \mathrm{ml}\left[{ }^{14} \mathrm{C}\right]$ cholesterol the ratios of cell-associated $\left[{ }^{3} \mathrm{H}\right]$ to $\left[{ }^{14} \mathrm{C}\right]$ (i.e., desmosterol/cholesterol) at 2,4 , and $6 \mathrm{~h}$ of incubation were $1.09 \pm 0.02$, $1.09 \pm 0.06$, and $1.05 \pm 0.01$ (mean \pm SEM, $n=3$ ), respectively. Thus, LPDS-preincubated $\mathbf{J} 774$ cells have relatively high ACAT activity which is dependent on their ability to synthesize desmosterol. Furthermore, exogenously added desmosterol markedly stimulated ACAT in lovastatin-treated J774 cells.

To examine the role of endogenous desmosterol on LDLinduced ACAT activity in $\mathrm{J} 774$ macrophages, the cells were incubated with LDL in the absence or presence of lovastatin (Fig. 3 B). Confirming our previous reports $(6,10)$, J774 ACAT activity was shown to be markedly stimulated by the addition of exogenous native LDL (Fig. $3 B[L D L]$ ). When LDL was added to lovastatin-treated cells (Fig. $3 B$ [ $L O V$ $+L D L]$ ), ACAT activity was only slightly decreased (by $11 \%)^{3}$ In a related experiment we measured CE mass accumulation in control and lovastatin-treated J774 macrophages. When cells were incubated with $300 \mu \mathrm{g} / \mathrm{ml} \mathrm{LDL}$ for $24 \mathrm{~h}$ control cells accumulated $97.5 \pm 4.2 \mu \mathrm{g} \mathrm{CE} / \mathrm{mg}$ cell protein (and $4.6 \mu \mathrm{g}$ desmosteryl ester $/ \mathrm{mg}$ ) and lovastatin-treated cells accumulated $87.8 \pm 9.8 \mu \mathrm{g} \mathrm{CE} / \mathrm{mg}$ ( $n=3$, not statistically different). Thus, endogenous desmosterol synthesis is not needed for LDL-induced ACAT stimulation and CE accumulation in J774 macrophages.

Exogenous desmosterol stimulates ACAT and causes steryl ester accumulation in human monocyte-derived macrophages and mouse peritoneal macrophages. Our finding that exogenously added desmosterol stimulated ACAT in lovastatintreated $\mathrm{J} 774$ macrophages (Fig. $3 \mathrm{~A}$ ) and also in human fibroblasts (data not shown) prompted us to investigate the effect of desmosterol on ACAT activity in human monocyte-derived macrophages. In addition, we also tested the effect of two other shellfish sterols (24-methylene cholesterol and brassicasterol [16]) and five xanthomatosis-associated sterols (sitostanol, campesterol, campestanol, and sitosterol, which are elevated in the serum of patients with sitosterolemia [13], and cholestanol, which is elevated in patients with both sitosterolemia and CTX [13, 14]). The data in Fig. 4 show that $10 \mu \mathrm{g} / \mathrm{ml}$ desmosterol (obtained commercially or from LPDS-incubated J774 cells) stimulated ACAT 29- and 4-fold compared with

3. Under the conditions of this experiment, both specific and total ${ }^{125} \mathrm{I}$-LDL degradation were increased 1.4-fold in the lovastatin-treated cells. However, this increase in LDL degradation would not be expected to increase ACAT activity proportionately since ACAT stimulation by LDL is mostly saturated at $100 \mu \mathrm{g} / \mathrm{ml} \mathrm{LDL} \mathrm{(see} \mathrm{Fig.} 6$ in reference 5).

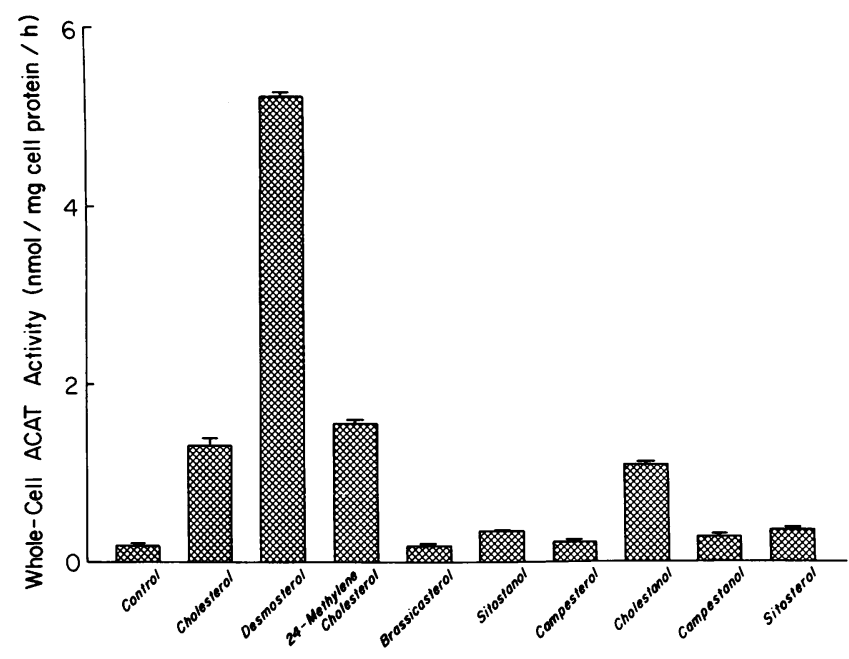

Figure 4. Whole-cell ACAT activity in human monocyte-derived macrophages incubated with shellfish sterols and xanthomatosis-associated sterols. Monolayers of human monocyte-derived macrophages, preincubated for $24 \mathrm{~h}$ in DME/LPDS, were incubated for $7 \mathrm{~h}$ with DME/LPDS alone (Control) or DME/LPDS containing 10 $\mu \mathrm{g} / \mathrm{ml}$ of the indicated sterols. The sterols were added to the media as described in the legend to Fig. 3; all incubation media, including the control media, contained $0.33 \%$ (vol/vol) ethanol. $\left[{ }^{14} \mathrm{C}\right]$ Oleatealbumin complex was added during the last $2 \mathrm{~h}$ of the 7-h incubation, and then the cells were assayed for steryl $\left[{ }^{14} \mathrm{C}\right]$ oleate content per milligram protein per $35-\mathrm{mm}$ dish. Values shown are means \pm SEM $(n=3)$. Separate cell uptake experiments (see Methods and text) indicated that at $7 \mathrm{~h}$ the cells took up (per milligram cell protein)

$7.12 \pm 0.33 \mu \mathrm{g}$ desmosterol and $5.63 \pm 0.36 \mu \mathrm{g}$ cholesterol, respectively.

control and cholesterol-treated cells, respectively. The greater potency of desmosterol over cholesterol as an ACAT stimulator in these two cell types could not be fully explained by greater cellular uptake of desmosterol compared with cholesterol; the ratios of cell-associated desmosterol to cholesterol at 2,4 , and $7 \mathrm{~h}$ were $1.44 \pm 0.03,1.39 \pm 0.03$, and $1.26 \pm 0.02$, respectively. Similar data were obtained with mouse peritoneal macrophages: $10 \mu \mathrm{g} / \mathrm{ml}$ desmosterol stimulated ACAT $\sim 70$ fold more than control levels and 5-fold more than the activity in cells treated with $10 \mu \mathrm{g} / \mathrm{ml}$ cholesterol despite similar cellular uptake of desmosterol and cholesterol (data not shown). Furthermore, although none of the other sterols tested in human macrophages were as potent as desmosterol in stimulating ACAT, 24-methylene cholesterol and cholestanol (both $>95 \%$ by HPLC) substantially stimulated ACAT above control levels and were approximately as potent as cholesterol as ACAT stimulators. Thus, exogenously added desmosterol markedly stimulated ACAT in human monocyte-derived macrophages, and 24-methylene cholesterol and cholestanol were equipotent with cholesterol as ACAT stimulators in these cells.

We next examined the effect of exogenously added desmosterol on steryl ester mass accumulation in human macrophages (Fig. 5). Cells incubated for $24 \mathrm{~h}$ in DME/LPDS (CON) contained only a small amount of steryl ester. The addition of $10 \mu \mathrm{g} / \mathrm{ml}$ cholesterol throughout the 24-h incubation increased steryl ester content threefold. In both the control and cholesterol-treated samples the sterol moiety of the steryl esters gave a single peak on GC that had the exact retention time of authentic cholesterol. The addition of $10 \mu \mathrm{g} / \mathrm{ml}$ desmosterol 


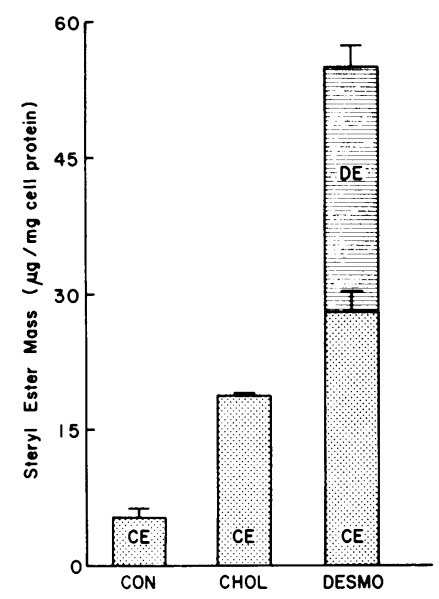

Figure 5. Steryl ester mass accumulation in human monocyte-derived macrophages incubated with cholesterol or desmosterol. Monolayers of human monocyte-derived macrophages, preincubated for 24 h with DME/10\% LPDS, were incubated for an additional $24 \mathrm{~h}$ with DME/LPDS alone $(C O N)$ or with DME/ LPDS containing $10 \mu \mathrm{g} / \mathrm{ml}$ cholesterol $(\mathrm{CHOL})$ or 10 $\mu \mathrm{g} / \mathrm{ml}$ desmosterol (DESMO). All incubation media, including control media, contained $0.33 \%$ (vol/vol) ethanol. At the end of the 24-h incubation period lipid extracts of the cells were assayed for free and total cholesterol and desmosterol mass by GC (see Methods). Shown are the values for $\mathrm{CE}$ and desmosteryl ester $(D E)$ mass per milligram protein per 60 -mm dish (means \pm SEM, $n=3$ ).

throughout the incubation period increased steryl ester accumulation tenfold over the control cells and threefold over the cholesterol-treated cells. In these desmosterol-treated cells the sterol moieties of the steryl esters were resolved into two GC peaks, equal in area, that had retention times identical to authentic cholesterol and authentic desmosterol, respectively. Thus, exogenously added desmosterol led to substantial steryl ester accumulation in human monocyte-derived macrophages; the steryl esters that accumulated appeared to consist of equal amounts of cholesteryl ester and desmosteryl ester. ${ }^{4}$

Steryl esters in macrophages undergo a continual cycle of ACAT-mediated esterification and neutral steryl ester hydrolysis (the so-called CE cycle; 31). Thus, the steryl ester mass measurements described above reflect the net result of these two processes (esterification and hydrolysis). The relatively greater potency of desmosterol vs. cholesterol in stimulating steryl ester accumulation could therefore be due to some combination of: (a) a relatively greater potency of desmosterol (vs. cholesterol) in ACAT stimulation; and (b) a relatively greater resistance of desmosteryl ester (vs. CE) to neutral steryl ester hydrolysis. That the former is clearly important was demonstrated by our data with both human monocyte-derived macrophages and mouse peritoneal macrophages (above) showing that desmosterol was markedly more potent than cholesterol in stimulating $\left[{ }^{14} \mathrm{C}\right]$ oleate incorporation into steryl esters in the whole-cell ACAT assay. This assay uses a relatively short $\left[{ }^{14} \mathrm{C}\right]$ oleate pulse time $\left(1-2 \mathrm{~h}\right.$ vs. a $t_{1 / 2}$ for steryl ester hydrolysis of $10-18 \mathrm{~h}$ [reference 31 and below]) and thus primarily measures ACAT activity independently of neutral steryl ester hydrolase activity.

4. We attempted to show that desmosterol-treated human macrophages, as compared with control-treated human macrophages, accumulated oil red $\mathrm{O}$-positive inclusions. However, control human macrophages themselves contained numerous oil red $\mathrm{O}$ inclusions, which we subsequently showed was due to tremendous amounts of triglyceride in these cells (unpublished data). Given this very high background of oil red O-positive inclusions, it was impossible to show that desmosterol treatment led to a increase in inclusions in these cells.
If, in addition to the clear role for ACAT in the desmosterol vs. cholesterol effect on steryl ester mass accumulation, there was also a role for neutral steryl ester hydrolysis, then we should be able to demonstrate that macrophages hydrolyze ACAT-derived desmosteryl ester to a lesser extent (and/or lesser rate) than ACAT-derived CE. To address this issue we used a method described by Brown et al. (31) to compare desmosteryl ester hydrolysis with CE hydrolysis in mouse peritoneal macrophages; these cells are known to have an active CE cycle (31), and, like human macrophages, demonstrate greater sterol esterification with desmosterol than with cholesterol (above). The cells were first induced to accumulate either ACAT-derived desmosteryl ester (by a 24-h incubation with desmosterol) or ACAT-derived CE (by a 24-h incubation with acetyl-LDL to obtain enough cellular CE accumulation for the purpose of the experiment). The loaded cells were then incubated (chased) for an additional $24 \mathrm{~h}$ in the absence of sterol but in the presence of the specific ACAT inhibitor, Sandoz compound 58-035, to prevent further esterification and reesterification of sterol (32). CE and desmosteryl ester contents were measured at the beginning $(0 \mathrm{~h}$, control), at $10 \mathrm{~h}$, and at the end ( $24 \mathrm{~h}$ ) of the 24-h chase period (Fig. 6); any decrease in the steryl ester content during the chase period is due to neutral steryl ester hydrolysis (31). In the case of the acetyl-LDLtreated cells we determined previously that $96 \%$ of the cellular $\mathrm{CE}$ that accumulates during a 24-h incubation is ACAT derived (Tabas, I., and W. Rosoff, unpublished data). Therefore, any subsequent decrease in cellular CE content is almost entirely due to neutral and not lysosomal CE hydrolysis. The data in Fig. 6 clearly show that desmosteryl ester (open circles) is hydrolyzed at the same rate and to the same extent as CE (closed circles). These data, together with the whole-cell ACAT assay data (above), demonstrate that the relatively greater po-

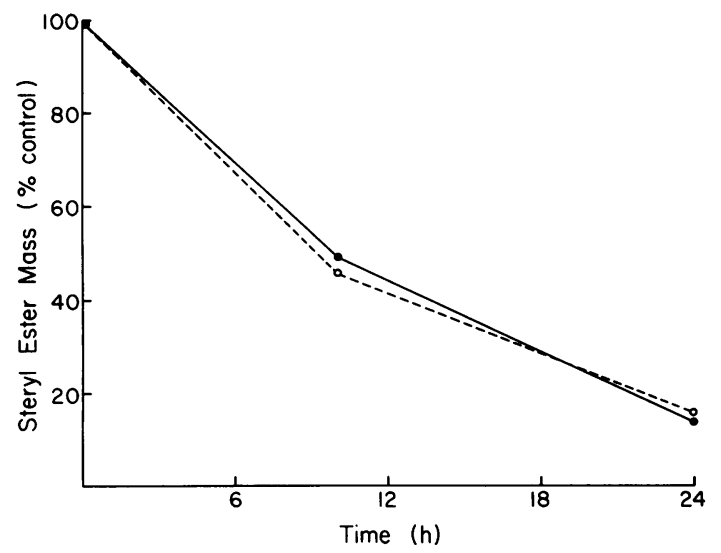

Figure 6. Hydrolysis of ACAT-derived steryl esters in mouse peritoneal macrophages. Monolayers of mouse peritoneal macrophages were incubated for $24 \mathrm{~h}$ with DME/10\% LPDS containing either 50 $\mu \mathrm{g}$ cholesterol $/ \mathrm{ml}$ acetyl-LDL or $25 \mu \mathrm{g} / \mathrm{ml}$ desmosterol. The cells were then washed with PBS and harvested immediately ( $0 \mathrm{~h}$, control) or incubated for an additional 10 or $24 \mathrm{~h}$ with DME/LPDS containing $10 \mu \mathrm{g} / \mathrm{ml} \mathrm{58-035}$. At the end of the incubation period lipid extracts of the cells were assayed for free and total cholesterol and desmosterol mass by GC. Shown are the values for CE mass in the acetyl-LDL-treated cells $(\bullet)$ and desmosteryl ester mass in the desmosterol-treated cells (O), expressed as percent of the respective steryl ester masses present in the $0 \mathrm{~h}$ (control) samples. The control values were $131.3 \pm 12.8 \mu \mathrm{g} \mathrm{CE}$ and $54.1 \pm 11.2 \mu \mathrm{g} \mathrm{DE} / \mathrm{mg}$ cell protein per 35-mm dish, respectively (means $\pm \operatorname{SEM}, n=3$ ). 
tency of desmosterol vs. cholesterol in stimulating steryl ester accumulation can be accounted for mostly (if not entirely) by the relatively greater potency of desmosterol vs. cholesterol as an ACAT stimulator.

\section{Discussion}

The intracellular sterol esterification pathway (the ACAT pathway) in macrophages is thought to play a key role in atherosclerotic foam cell formation (4). Stimulation or inhibition of this pathway would be expected to promote or retard, respectively, the development of foam cells $(4,10)$. In this paper we have explored the macrophage ACAT reactivity (and thus the potential atherogenicity) of desmosterol and other noncholesterol sterols found in shellfish and associated with the foam cell diseases sitosterolemia and CTX.

Desmosterol represents $31 \%$ of the sterol in the sterol-rich shellfish, Alaskan king crab (15). Furthermore, this sterol has been implicated as an atherogenic sterol in several animal studies $(18,19)$ including one study with gerbils (19) in which elevated plasma desmosterol levels were associated with an increased number of atherosclerotic lesions. In this paper desmosterol was shown to be a potent stimulator of the macrophage ACAT reaction (Fig. 4). In addition, human macrophages were shown to accumulate substantial amounts of steryl ester when incubated with a rather low concentration $(10 \mu \mathrm{g} / \mathrm{ml})$ of desmosterol (Fig. 5). Half of the steryl esters formed were desmosteryl ester and half were CE. Whether the $\mathrm{CE}$ formed was due to conversion of the internalized desmosterol to cholesterol before esterification or to stimulation of esterification of endogenous cellular cholesterol (see references 8 and 9) by desmosterol has not yet been determined. ${ }^{5}$ The steryl esters in atherosclerotic foam cells are generally considered to consist of CE (reviewed in reference 33). However, in one experiment in which rabbits were fed a diet containing a small amount of desmosterol $(0.05 \%)$ as well as cholesterol, atherosclerotic lesions contained a substantial amount of desmosterol (38\% of lesion sterol; 18). Thus, this rabbit study and our findings raise the possibility that other steryl esters (e.g., desmosteryl ester) may accumulate in foam cells under certain conditions (i.e., a diet rich in desmosterol-containing shellfish).

Our data with the other sterols suggest that another shellfish sterol, 24-methylene cholesterol (which represents 26, 20,

5. We have determined that when $10 \mu \mathrm{g} / \mathrm{ml}\left[{ }^{3} \mathrm{H}\right]$ desmosterol was added to human macrophages for $24 \mathrm{~h}, 24 \%$ of the label was in cholesterol and $76 \%$ was in desmosterol. In $24 \mathrm{~h}$ human macrophages incubated with $10 \mu \mathrm{g} / \mathrm{ml}$ desmosterol accumulated $38.6 \mu \mathrm{g} / \mathrm{mg}$ total desmosterol; thus we may assume (given the $24 \%$ conversion data) that $50.6 \mu \mathrm{g} / \mathrm{mg}$ desmosterol entered the cell, of which $38.6 \mu \mathrm{g} / \mathrm{mg}(76 \%)$ remained desmosterol and $12 \mu \mathrm{g} / \mathrm{mg}(24 \%)$ was converted to cholesterol. If all of this desmosterol-derived cholesterol were esterified, the mass of CE (taking into account the fatty acid moiety) from this source would be $20.4 \mu \mathrm{g} / \mathrm{mg}$. The cells, in fact, accumulated $27.8 \mu \mathrm{g} / \mathrm{mg} \mathrm{CE}$ (Fig. 5). Thus, it is possible that most or all of the cholesterol esterified in desmosterol-treated human macrophages could have been derived from the internalized desmosterol. However, since desmosterol is a potent ACAT stimulator in these cells, and since a major substrate for ACAT is endogenous cellular cholesterol $(8,9)$, at least some of the cholesterol esterified by the cells was probably derived from endogenous cellular stores. and $20 \%$ of the sterols in oysters, clams, and scallops, respectively [16]), may also be atherogenic. Relevant to this issue is the finding by Conner and Lin (17) that shellfish sterols are intestinally absorbed in man and, unlike sitosterol, do not block the absorption of cholesterol. In contrast to our findings with desmosterol and 24-methylene cholesterol, most of the xanthomatosis-associated sterols did not stimulate human macrophage ACAT. Only cholestanol showed reactivity equipotent with cholesterol, but the plasma level of this sterol in sitosterolemia and CTX is only $2 \%$ of that of cholesterol (13, 14). Thus, the mechanism of excessive foam cell formation in these diseases must involve factors other than ACAT hyperreactivity of their associated sterols.

Our finding that macrophages can esterify desmosterol and that macrophage ACAT can be stimulated by other sterols (24-methylene cholesterol and cholestanol), as well as other studies showing that isolated microsomes from other cell types can catalyze the esterification of noncholesterol sterols (11, 12), probably suggests that ACAT has a somewhat relaxed sterol specificity. Alternatively, but less likely, it is possible that there is more than one sterol-esterifying enzyme. We have determined that the ACAT inhibitor, compound 58-035, effectively inhibits (by $83 \%$ ) the esterification of desmosterol in J774 macrophages (unpublished data), but this finding does not necessarily indicate the existence of one sterol-esterifying enzyme. Regarding ACAT's sterol specificity, we have shown that exogenous desmosterol is a more potent stimulator of ACAT than exogenous cholesterol in both human and mouse macrophages, despite only slightly greater cellular uptake of desmosterol. Assuming that there is one sterol-esterifying enzyme the explanation for this finding may be that either desmosterol is a better ACAT substrate and/or stimulator than cholesterol, or that desmosterol is transported to the enzyme more efficiently than cholesterol.

Our exploration of the effects of desmosterol on intracellular sterol esterification was undertaken after we discovered that J774 macrophages had a complete defect in cholesterol biosynthesis and instead accumulated desmosterol and desmosteryl ester. The $\mathbf{J} 774$ macrophage cell line used in our laboratory (see note added in proof in reference 9) is a unique foam cell model since both native and modified forms of LDL induce CE accumulation $(6,20)$, whereas other models (e.g., mouse peritoneal and human monocyte-derived macrophages) accumulate CE only with modified forms of LDL (4). The ability of J774 macrophages to accumulate CE, especially in the presence of native LDL, is highly dependent on a hyperactive ACAT pathway in these cells (10). J774 ACAT activity is relatively high even in the absence of exogenous lipoproteins or sterols (see Fig. $3 A$ and reference 21 ), and it is precisely under these conditions that the cells synthesize the ACAT stimulator, desmosterol (above). Thus, we initially considered the following hypothesis: before LDL exposure J774 ACAT is maintained in a primed, or active, state by endogenously synthesized desmosterol, and it is this primed ACAT pathway that then contributes to LDL-induced CE accumulation upon subsequent addition of the lipoprotein. However, the data in Fig. 3 support a role for desmosterol in $\mathbf{J} 774$ cells only in maintaining high ACAT activity in LPDS (Fig. $3 A$ ). The ability of LDL to stimulate ACAT activity and CE accumulation in these cells is not dependent on desmosterol-induced stimulation of sterol esterification before LDL addition (Fig. $3 \mathrm{~B}$ ).

In summary, we demonstrated that the $\mathbf{J} 774$ macrophage 
foam cell model has a complete defect in cholesterol biosynthesis and accumulates desmosterol and desmosteryl ester. In addition, we have shown that exogenously added desmosterol is a potent stimulator of sterol esterification and sterol ester accumulation in human monocyte-derived macrophages and mouse peritoneal macrophages and that 24-methylene cholesterol also stimulates human macrophage ACAT. There are several potential implications of our findings. With respect to J774 cells, the fact that their sterol content can be made to consist of almost $100 \%$ desmosterol (see Results) may be useful in constructing experimental systems in a macrophage foam cell model in which exogenous cholesterol transport and metabolism in the cells and excretion from the cells can be easily distinguished from pathways involving (or complicated by) endogenous cellular sterol. A similar strategy using mouse L cells, a nonmacrophage cell line that also accumulates desmosterol (34), was used by Rothblat and Buchko (35). In addition, if the cells are truly lacking the 24-reductase enzyme, the system may be suitable for studying and isolating (e.g., by transfection) the enzyme and its gene. Alternatively, if the enzyme is present but inhibited, aspects of regulation of the 24-reductase pathway may be amenable to study.

With respect to the ability of exogenous desmosterol and 24-methylene cholesterol to stimulate ACAT in human macrophages, our study together with the animal studies $(18,19)$ and shellfish diet study (17) cited above suggests that shellfish containing desmosterol, such as Alaskan king crab and other shellfish (e.g., oysters, clams, and scallops) may be atherogenic. Finally, the lack of ACAT reactivity of most of the xanthomatosis-associated sterols suggests that the excessive foam cell formation seen in these diseases must involve factors other than excessive stimulation of ACAT by the sterols themselves.

\section{Acknowledgments}

The authors thank Dr. Alan Tall for helpful discussions and for his critical review of this manuscript.

This work was supported by National Institutes of Health grants HL-21006, 39703, and 38312, and AI-26702. Dr. Tabas and Dr. Feinmark are Established Investigators of the American Heart Association and Boehringer Ingelheim, Inc.

\section{References}

1. Schaffner, T., K. Taylor, E. J. Bantucci, K. Fischer-Dzoga, J. H. Beeson, S. Glagov, and R. Wissler. 1980. Arterial foam cells with distinctive immunomorphologic and histochemical features of macrophages. Am. J. Pathol. 100:57-80.

2. Gerrity, R. G. 1981. The role of the monocyte in atherogenesis. I. Transition of blood-borne monocytes into foam cells in fatty lesions. Am. J. Pathol. 103:181-190.

3. Faggioto, A., R. Ross, and L. Harker. 1984. Studies of hypercholesterolemia in the nonhuman primate. I. Changes that lead to fatty streak formation. Arteriosclerosis. 4:323-340.

4. Brown, M. S., and J. L. Goldstein. 1983. Lipoprotein metabolism in the macrophage: implications for cholesterol deposition in atherosclerosis. Annu. Rev. Biochem. 52:223-261.

5. Tabas, I., and G. Boykow. 1987. Protein synthesis inhibition in mouse peritoneal macrophages results in increased acyl coenzyme A: cholesterol acyl transferase activity and cholesteryl ester accumulation in the presence of native low density lipoprotein. J. Biol. Chem. 262:12175-12181.

6. Tabas, I., D. A. Weiland, and A. R. Tall. 1985. Unmodified low density lipoprotein causes cholesteryl ester accumulation in J774 macrophages. Proc. Natl. Acad. Sci. USA. 82:416-420.

7. Suckling, K. E., and E. F. Stange. 1985. Role of acyl-CoA:cholesterol acyl transferase in cellular cholesterol metabolism. J. Lipid Res. 26:647-671.

8. Brown, M. S., S. E. Dana, and J. L. Goldstein. 1975. Receptordependent hydrolysis of cholesteryl esters contained in plasma low density lipoprotein. Proc. Natl. Acad. Sci. USA. 72:2925-2929.

9. Tabas, I., W. J. Rosoff, and G. Boykow. 1987. Acyl coenzyme A: cholesterol acyl transferase in macrophages utilizes a cellular pool of cholesterol oxidase-accessible cholesterol as substrate. J. Biol. Chem. 263:1266-1272.

10. Tabas, I., D. A. Weiland, and A. R. Tall. 1986. Inhibition of acyl Co A:cholesterol ester transferase in $\mathbf{J} 774$ macrophages enhances down-regulation of the low density lipoprotein receptor and 3-hydroxy-3-methylglutaryl coenzyme A reductase and prevents low density lipoprotein-induced cholesterol accumulation. J. Biol. Chem. 261:3147-3155.

11. Macauley, S. K., J. T. Billheimer, and K. S. Ritter. 1986. Sterol substrate specificity of acyl coenzyme A:cholesterol acyltransferase from the corn earworm, Heliothis zea. J. Lipid Res. 27:64-71.

12. Lichtenstein, A. H., and P. Brecher. 1983. Esterification of cholesterol and 25-hydroxycholesterol by rat liver microsomes. Biochim. Biophys. Acta. 751:340-348.

13. Salen, G., P. O. Kwiterovich, Jr., S. Shefer, G. S. Tint, V. Horak, V. Shore, B. Dayal, and E. Horak. 1985. Increased plasma cholestanol and $5 \alpha$-saturated plant sterol derivatives in subjects with sitosterolemia and xanthomatosis. J. Lipid Res. 26:203-209.

14. Salen, G. 1971. Cholestanol deposition in cerebrotendinous xanthomatosis: a possible mechanism. Ann. Intern. Med. 75:843-851.

15. Idler, D. R., and P. Wiseman. 1968. Desmosterol and other sterols of the alaskan king crab and the north atlantic queen crab. Comp. Biochem. Physiol. 26:1113-1117.

16. Kritchevsky, D., A. S. Tepper, N. W. DiTullo, and W. Holmes. 1967. The sterols of seafood. J. Food Sci. 32:64-66.

17. Conner, W. E., and D. S. Lin. 1981. Absorption and transport of shellfish sterols in human subjects. Gastroenterology. 81:276-284.

18. Steinberg, D., and J. Avigan. 1962. Deposition of desmosterol in the lesions of experimental atherosclerosis. Lancet. i:572.

19. Wong, H. Y. C., H. E. Vroman, and H. C. Mendez. Atherogenic aspects of desmosterol metabolism caused by prolonged triparanol administration. 1966. Life Sci. 5:629-637.

20. Kita, T., M. S. Brown, and J. L. Goldstein. 1980. Feedback regulation of 3-hydroxy-3-methylglutaryl coenzyme A reductase in livers of mice treated with mevinolin, a competitive inhibitor of the reductase. J. Clin. Invest. 66:1094-1100.

21. Tabas, I., G. C. Boykow, and A. R. Tall. 1987. Foam cellforming $\mathbf{J} 774$ macrophages have markedly elevated acyl coenzyme A:cholesterol acyl transferase activity compared with mouse peritoneal macrophages in the presence of low density lipoprotein (LDL) despite similar LDL receptor activity. J. Clin. Invest. 79:418-426.

22. Wright, S. D., and S. C. Silverstein. 1982. Tumor-promoting phorbol esters stimulate $\mathrm{C} 3 \mathrm{~b}$ and $\mathrm{C} 3 \mathrm{~b}^{\prime}$ receptor-mediated phagocytosis in cultured human monocytes. J. Biol. Chem. 255:3134-3140.

23. Lowry, O. H., N. J. Rosebrough, A. L. Farr, and R. J. Randall. 1951. Protein measurement with the Folin phenol reagent. J. Biol. Chem. 193:265-275.

24. Folch, J., I. Ascoli, M. Lees, J. A. Meath, and F. N. LeBaron. 1951. Preparation of lipid extracts from brain tissue. J. Biol. Chem. 191:833-841.

25. Goldstein, J. L., S. K. Basu, and M. S. Brown. 1983. Receptormediated endocytosis of low-density lipoprotein in culture cells. Methods Enzymol. 98:241-260.

26. Bligh, E. G., and W. J. Dyer. 1959. A rapid method for total lipid extraction and purification. Can. J. Biochem. Physiol. 37:911917.

27. Trzaskos, J. M., W. D. Bowens, A. Shafiee, R. T. Fischer, and 
J. L. Gaylor. 1984. Cytochrome P-450-dependent oxidation of lanosterol in cholesterol biosynthesis. J. Biol. Chem. 259:13402-13412.

28. Copius, J. W., and H. W. Beekes. 1965. The analysis of animal and vegetable fats. J. Chromatogr. 17:99-113.

29. Galli, G., and S. Maroni. 1967. Mass spectrometric investigations of some unsaturated sterols biosynthetically related to cholesterol. Steroids. 10:189-197.

30. Alberts, A. W., et al. 1980. Mevinolin: a highly potent competitive inhibitor of hyroxymethylglutaryl-coenzyme A reductase and a cholesterol-lowering agent. Proc. Natl. Acad. Sci. USA. 77:3957-3961.

31. Brown, M. S., Y. K. Ho, and J. L. Goldstein. 1980. The cholesterol ester cycle in macrophage foam cells. J. Biol. Chem. 255:93449352.
32. Ross, A. C., K. J. Go, J. G. Heider, and G. H. Rothblat. 1984. Selective inhibition of acyl-CoA:cholesterol acyl transferase by compound 58-035. J. Biol. Chem. 259:815-819.

33. St. Clair, R. W. 1976. Metabolism of the arterial wall and atherosclerosis. Atheroscler. Rev. 1:61-117.

34. Rothblat, G. H., C. H. Burns, R. L. Conner, and J. R. Laundrey. 1970. Desmosterol as the major sterol in L-cell mouse fibroblasts grown in sterol-free culture medium. Science (Wash. DC). 169:880882.

35. Rothblat, G. H., and M. K. Buchko. 1971. Effect of exogenous steroids on sterol synthesis in L-cell mouse fibroblasts. J. Lipid Res. 12:647-652. 